\title{
Determination of Resistance Cumhuriyet-75 and Selimiye-95 Wheat (Triticum Aestivum L.) Varieties Against to Some Abiotic Stress Factories
}

\author{
Nezahat Turfan ${ }^{1 *}$, Ekrem Mutlu² \\ ${ }^{1}$ Department of Biology, Faculty of Arts and Sciences, Kastamonu University, 37200 Kastamonu, Turkey \\ ${ }^{2}$ Aquaculture Department, Faculty of Fisheries, Kastamonu University, 37200 Kastamonu, Turkey
}

\section{A R T I C LE INFO}

\section{Research Articles}

Received 09 March 2018

Accepted 18 March 2018

\section{Keywords:}

Abiotic Stresses

Cumhuriyet-75

Selimiye-95

Tolerance

\section{*Corresponding Author:}

E-mail: nturfan@kastamonu.edu.tr

\section{A B S T R A C T}

In this study, resistance mechanism of two wheat genotypes against salt, heavy metal, lime and drought $(50 \%)$ treatments were investigated in summer Cumhuriyet-75 and winter Selimiye-95. According to results chlorophyll a, b, total chlorophyll and carotenoid level increased in $\mathrm{FeCl}_{3}$, drought and $225 \mathrm{mM} \mathrm{NaCl}$ in Cumhuriyet-75 but they were higher at $\mathrm{NaCl}, \mathrm{FeCl}_{3}$ and $\mathrm{ZnCl}_{2}$ treatments in Selimiye-95 comparison to control. While $\mathrm{H}_{2} \mathrm{O}_{2}$ content rose all stres treatments in both varieties but Malondialdehyde (MDA) decreased in Selimiye with all applications. The amount of proline is lower in Cumhuiyet-75 but higher in Selimiye-95. Total soluble protein was found higher at salt concentartion and drought in both varieties. Ascorbate peroxidase (APX), Süperoxide dismutase (SOD) activity increased in salt and $\mathrm{FeCl}_{3}$ in Selimiye-95 but SOD ativity were higher at salt treatments in Cumhuriyet-75. And also in both varieties APX and Guaiacol peroxidase (GuPX) increased at $\mathrm{FeCl}_{3}$ but Catalase (CAT) were higher in only $\mathrm{FeCl}_{3}$ in Cumhuriyet-75. As a result Selimiye-95 showed tolerance to salt and $\mathrm{FeCl}_{3}$ with high photosynthetic pigment, proline and soluble protein content with lower MDA but it is sensitive to $\mathrm{NiCl}_{2}$ and drought. Whereas Cumhuriyet-75 cultivar is resistan to drought, $\mathrm{FeCl} 3$ and $225 \mathrm{mM} \mathrm{NaCl}$ depended on pigment, protein content and APX, CAT, GuPX and SOD activities. When all the data are taken into consideration, it was concluded that the responses of the varieties to the treatments changed according to the type and concentration of stress, and Selimiye-95 variety was tolerant compared to Cumhuriyet- 75 variety.

\section{Cumhuriyet-75 ve Selimiye-95 Buğday Çeşitlerinin Bazı Abiyotik Stres Faktörlerine Toleranslarının Belirlenmes}
M A K A L E B İ L G İ S İ
Ö Z E T

\section{AraștırmaMakalesi}

Geliş 09 Mart 2018

Kabul 18 Mart 2018

Anahtar Kelimeler:

Abiyotik Stres

Cumhuriyet-75

Selimiye-95

Tolerans

*Sorumlu Yazar:

E-mail: nturfan@kastamonu.edu.tr
Bu çalışmada Cumhuriyet-75 ve Selimiye-95 buğday çeşitlerinin tuz, ağır metal, kireç ve kurak (\%50) uygulamalarına toleransları araştırılmıștır. Bulgulara göre Cumhuriyet-75'te klorofil a, klorofil b, toplam klorofil ve karotenoit miktar1 $\mathrm{FeCl}_{3}$, kurak ve $225 \mathrm{mM} \mathrm{NaCl}$ uygulamalarında kontrole göre artış gösterirken Selimiye-95'te $\mathrm{NaCl}$ konsantrasyonları, $\mathrm{FeCl}_{3}$ ve $\mathrm{ZnCl}_{2}$ uygulamalarında en yüksek değere ulaşmıştır. Hidrojen peroksit miktarı $\left(\mathrm{H}_{2} \mathrm{O}_{2}\right)$ miktarı her iki buğday çeşidinde yüksektir ancak malondialdehit (MDA) miktarı Selimiye-95'te tüm uygulama gruplarında azalmıştır. Prolin içeriği Cumhuriyet'te tüm uygulama gruplarında azalırken Selimiye-95'te artmıştır. Toplam çözünür protein her iki buğday çeşidinde $\mathrm{NaCl}$ konsantrasyonları ve kuraklık uygulamasında yüksek bulunmuştur. Askorbat peroksidaz (APX) ve Süperoksit dismutaz (SOD) aktivitesi Selimiye-95'te $\mathrm{NaCl}$ ve $\mathrm{FeCl}_{3}$ uygulamasinda, Cumhuriyet-75'te ise SOD aktivitesi $\mathrm{NaCl}$ uygulamalarında yüksek bulunmuştur. Ayrıca APX ve Guaiakol peroksidaz (GuPX) aktivitesi her iki çeşitte $\mathrm{FeCl}_{3}$ uygulamasında artış gösterirken, CAT aktivitesi sadece Cumhuriyet-75'te $\mathrm{FeCl}_{3}$ uygulamasında yüksektir. Sonuç olarak Selimiye-95 buğday çeşidi yüksek pigment içeriği, prolin, çözünür protein ve düşük MDA değeri ile $\mathrm{NaCl}$ konsantrasyonları ve $\mathrm{FeCl}_{3}$ uygulamalarına tolerans gösterirken, $\mathrm{NiCl}_{2}$ ve kuraklık uygulamalarına ise duyarlı bulunmuştur. Cumhuriyet- 75 çeşidi pigment, protein miktarı ve APX, Katalaz (CAT), GuPX ve SOD aktivite değerlerine bağlı olarak kuraklık, $\mathrm{FeCl}_{3}$ ve $225 \mathrm{mM} \mathrm{NaCl}$ uygulamalarına dayanıklıdır. Tüm veriler değerlendirildiğine çeşitlerin stres uygulamalarına tepkisi stresin çeşidi ve konsantrasyonuna göre değiştiği ve ayrıca Selimiye-95 çeşidinin Cumhuriyet-75'e göre dayanıklı olduğu sonucuna varılmıştır. 


\section{Introduction}

Wheat ranks first in terms of area of planting and production in field crops due to its being a good source of nutrients, its broad adaptation limits and ease of transport, storage and processing. Wheat is grown in almost every part of our country however most of the wheat grown in our country $(80 \%)$ is grown under rain-dependent conditions. Moreover, the general warmt and drought climatic conditions of our country create the ideal environment for salinity and barrenness formation (Öztürk and Aydın, 2004; Başer et al., 2005). The accumulation of zinc, iron, lead, cadmium, nickel and other heavy metals in dense industrial zones close to cultivated lands affect crop production by leading to heavy metal toxicity. As is seen, wheat production areas are not uniform, some factors required for growth and development are wanting while some factors are far from being optimal. The cited conditions affect wheat production and cause loss of quality and efficiency (Gupta et al., 2011; Öz et al., 2016). As such, it is very important to rehabilitate and utilize such agricultural areas in an economic and economical way. Due to the increased nutrient requirements and the limited availability of agricultural lands in parallel with population increase, selecting genotypes with high tolerance to stress factors in the regions where salinity, lime/drought and heavy metal toxicity are dominant will contribute to more efficient utilization of existing land resources. Determination of morphological parameters as well as physiological measurements in the varieties in order to determine the mechanism of resistance to stress factors will enable more accurate steps to be taken for determining the appropriate species and varieties. It is reported that changes in photosynthetic activity are the main factors that decrease yield and quality in wheat within this context (Makino, 2001; Molas, 2006). Öncel and Keleş (2002), Blake et al. (2007), Razi et al. (2016) have reported that abiotic stress conditions, salinity, heavy metal toxicity and drought change the leaf morphology of wheat and causes oxidative stress in the leaf tissue thereby damaging the chloroplast membrane respectively. While decrease in area and length of leaf cause reduction of the photosynthesis capacity, oxidative stress leads to degradation of chloroplast structure thereby breaking up the pigments, reducing enzyme activities responsible for chlorophyll synthesis and consequently decreasing the amount of photosynthetic pigments (Hernandez et a 2001; Çimen et al., 2013). The amounts of proline (Chen et al., 2001), total soluble protein (Nagoor, 1999; Sharma and Dietz, 2006), soluble carbohydrates and starch (Pattanagul and Thitisaksakul, 2008) also vary in wheat under stress conditions. Furthermore, stress conditions increase the accumulation of ROS such as hydrogen peroxide, hydroxy radicals, singlet oxygen and superoxide anions (Kholová et al., 2010) Excessive ROS accumulation causes excessive accumulation of malondialdehyde (MDA) which induces peroxidation in membrane lipids causing protein, DNA, RNA denaturation (Neto et al., 2006). Researchers have reported that the activity of enzymes such as ascorbate peroxidase (APX), catalase (CAT), superoxide dismutase (SOD) and peptidase (POD) have a role in reducing oxidative stress and lipid peroxidation damage in tolerant species (Terzi and Yildiz, 2013). That said, yield and quality in wheat vary according to the ecological structure of the region and the applied cultivation processes (Zheng et al., 2009; Waters et al., 2009). Effects of salt, heavy metals, drought and lime treatments in green parts photosynthetic pigments, proline, total soluble protein, $\mathrm{MDA}, \mathrm{H}_{2} \mathrm{O}_{2}$ amount and APX, CAT, GuPX and SOD activities of summer Cumhuriyet-75 and winter Selimiye-95 variety wheat bread genotypes have been researched in this study.

\section{Material and Method}

\section{Plant Material}

Cumhuriyet-75 (bread type) variety registered by the Ege (Agean) Institute of Agricultural Research in 1976 and Selimiye-95 (bread) variety produced by crossbreeding registered Trakya (Thrace) Institute of Agricultural Research in 2009 were used in the study. Cumhuriyet-75 is a summer type spiny wheat which that the biggest grain among the white wheat varieties. Its planting is recommended in coastal zones and rural and basal areas. Selimiye-95 is a winter variety without spines. It is recommended for regions where planting is made in winter.

\section{Planting Operations of Varieties}

The study was launched in $3^{\text {rd }}$ week of October. 25 seeds were planted in a pot with three replications for each treatment group in each pot. The pots have a volume of $5 \mathrm{~L}$ in and consist of a mixture in ration of garden turf: peat: sand (1: 1: 1). Salt treatment $(75 \mathrm{mM}, 150 \mathrm{mM}$ and $225 \mathrm{mM} \mathrm{NaCl})$, heavy metal treatment $(0.2 \mathrm{mg} / \mathrm{L}$ in the form of $\mathrm{FeCl}_{3}, \mathrm{NiCl}_{2}$ and $\mathrm{ZnCl}_{2}$ ) and lime treatment (2 $\mathrm{mg} / \mathrm{L}$ in the form of $\mathrm{CaCO}_{3}$ ) were solubilized in tap water with ds 0.04 and with freshly prepared solutions each time. For $50 \%$ drought treatments trap water was used $275 \mathrm{ml} \mathrm{kg} \mathrm{kg}^{-1}$. The treatments were made while the seedlings were at 4-5 leaf stage by treatment of twice a week for week five weeks. After five weeks, the fully expanded leaf was randomly collected. In leaf sample photosynthetic pigments as chlorophyll a, chlorophyll b, total chlorophyll and carotenid, lipid peroxidation level (malondialdehyde-MDA), hydrogen peroxide $\left(\mathrm{H}_{2} \mathrm{O}_{2}\right)$, glucose and starch amount as well as APX, CAT, GuPX and SOD activities were determined.

\section{Chemical Analyzes}

Chlorophyll content of the leaves was measured by the method of Arnon (1949). Carotenoid amount was estimated by Jaspars Formulated according to the method Witham et al. (1971). Proline content was determined according to the modified method of Bates et al. (1973). Total soluble protein contents were determined according to the method of Bradford (1976) using the Bio-Rad assay kit with bovine serum albumin as a calibration standard. The level of lipid peroxidation products was determined and expressed as MDA content according to Luts et al. (1996). Hydrogen peroxide in the plant samples was determined by the method of Velikova et al. (2000). 
The extracts were prepared from first three leaves of the plants which were treated by control and stress. Accordingly, nearly $0.5 \mathrm{~g}$ fresh leaf samples were homogenized with $50 \mathrm{mM}$ ( $\mathrm{pH}$ 7.6) phosphate buffer solution $(10 \mathrm{~mL})$ ground in liquid nitrogen and containing $0.1 \mathrm{mM}$ Na-EDTA (Ethylenediaminetetraacetic acid). The homogenized samples were centrifuged for $15 \mathrm{~min}$ at $15000 \mathrm{~g}$ and $+4{ }^{\circ} \mathrm{C}$, and then the enzyme activities in the resulting supernatant were determined according to the methods of Çakmak (1994). Catalase (CAT), ascorbate peroxidase (APX), guaiacol peroxidase (GuPX) and superoxide dismutase (SOD) activities were measured according to the methods of Bergmeyer (1974), Nakano and Asada (1981), Chance and Maehley (1995) and respectively under nitro blue tetrazolium chloride (NBT) light by $\mathrm{O}_{2}^{-}$reduction

\section{Statistical Analysis of Data}

The statistical analysis of the data obtained as a result of the study was conducted according to the ANOVA and Tukey tests at $95 \%$ confidence interval by virtue of the SPSS 20 program.

\section{Results}

Photosynthetic pigments showed differences basing on wheat varieties and stress treatments. While chlorophyll a, chloropphyll b, total chlorophyll and carotenoid levels increased in drought, $\mathrm{FeCl}_{3}, 225 \mathrm{mM}$ and $75 \mathrm{mM} \mathrm{NaCl}$ compared to control group but it was lower in other treatments in Cumhuriyet-75. The lowest values of those pigments were obtained with $\mathrm{NiCl}_{2}$, $\mathrm{CaCO}_{3}$ and $\mathrm{ZnCl}_{2}$ applications in orderly (Table 1). It was found that the amount of chlorophyll a was lowest value in $75 \mathrm{mM} \mathrm{NaCl}$ while chlorophyll b content lowered in drought, $\mathrm{NiCl}_{2}$ and $\mathrm{CaCO}_{3}$ treatments in Selimiye-95 respectively. Whereas total chlorophyll content increased with salts, $\mathrm{FeCl}_{3}$ and $\mathrm{ZnCl}_{2}$ treatments but increased in drought and $\mathrm{NiCl}_{2}$. And also total carotenoid amount was lower at $\mathrm{CaCO}_{3}$ only in Selimiye-95 (Table 1).

The proline content of Cumhuriyet-75 decreased in all stress treatments but it was found higher in Selimiye-95 with respect to control plants (Table 2). In Cumhuriyet-75 the amount of proline was lowest in $50 \%$ drought (53.64\%), in $\mathrm{ZnCl}_{2}$ (45.26\%), in $\mathrm{NiCl}_{2}$ (44.92\%). But the highest proline values were determined in $\mathrm{CaCO}_{3}$ (74.62 $\%), \mathrm{FeCl}_{3}(64.13 \%), \mathrm{NiCl}_{2}(50.22 \%)$ in Selimiye-95 (Table 2). In Cumhuriyet the total soluble protein content was found lower in $\mathrm{NiCl}_{2}, \mathrm{ZnCl}_{2}$ and $\mathrm{CaCO}_{3}$ but it was lowest in only heavy metals treated plants in Selimiye-95 variety compared to control seedling (Table 2). Increasing in the content of soluble protein was determined in 150 $\mathrm{mM} \mathrm{NaCl}$ as $94.35 \%$, in $225 \mathrm{mM} \mathrm{NaCl}$ as $90.5 \%, 75$ $\mathrm{mM} \mathrm{NaCl}$ as $74.46 \%$ and in $\mathrm{FeCl}_{3}$ as $14.2 \%$ for Cumhuriyet-75 (Table 2). In Selimiye-96 content of protein increased with salt concentration. The lowest amount of protein was recorded in $\mathrm{NiCl}_{2}$ (31.28\%), $\mathrm{FeCl}_{3}(17.49 \%)$ and $\mathrm{ZnCl}_{2}(9.97 \%)$ treatments (Table 2).

Table 1 Effects of salt, heavy metals, lime and drought (50\%) treatments in clorophyll a, chlorophyll b, total chlorophyll, ratio of chloroghyll a/ chlorophyll b and carotenoids content in the Cumhuriyet-75 and Selimiye-95 variety.

\begin{tabular}{|c|c|c|c|c|c|}
\hline \multirow{2}{*}{$\mathrm{T}$} & \multicolumn{5}{|c|}{ Cumhuriyet } \\
\hline & Chl a & Chl b & Tot. Chl & $\mathrm{Chl} \mathrm{a/b}$ & Tot.Car. \\
\hline Control & $0.152 \pm 0.001^{\mathrm{d}}$ & $0.104 \pm 0.0004^{\mathrm{f}}$ & $0.256 \pm 0.0001^{\mathrm{e}}$ & $1.459 \pm 0.010^{\mathrm{cd}}$ & $8.01 \pm 0.02^{\mathrm{d}}$ \\
\hline $75 \mathrm{mM}$ & $0.153 \pm 0.001^{\mathrm{e}}$ & $0.096 \pm 0.0003^{\mathrm{d}}$ & $0.249 \pm 0.0004^{\mathrm{d}}$ & $1.582 \pm 0.010^{\mathrm{d}}$ & $8.01 \pm 0.02^{\mathrm{d}}$ \\
\hline $150 \mathrm{mM}$ & $0.151 \pm 0.001^{\mathrm{d}}$ & $0.099 \pm 0.0003^{\mathrm{e}}$ & $0.250 \pm 0.0003^{\mathrm{d}}$ & $1.528 \pm 0.010^{\mathrm{cd}}$ & $7.96 \pm 0.01^{\mathrm{d}}$ \\
\hline $225 \mathrm{mM}$ & $0.153 \pm 0.001^{\mathrm{e}}$ & $0.108 \pm 0.0004^{\mathrm{g}}$ & $0.260 \pm 0.0005^{\mathrm{f}}$ & $1.413 \pm 0.001^{\mathrm{c}}$ & $7.86 \pm 0.01^{\mathrm{d}}$ \\
\hline $\mathrm{FeCl}_{3}$ & $0.154 \pm 0.001^{\mathrm{e}}$ & $0.154 \pm 0.0001^{\mathrm{h}}$ & $0.307 \pm 0.0003^{\mathrm{h}}$ & $1.000 \pm 0.001^{\mathrm{b}}$ & $8.26 \pm 0.03^{\mathrm{e}}$ \\
\hline $\mathrm{NiCl} 2$ & $0.094 \pm 0.001^{\mathrm{a}}$ & $0.032 \pm 0.0005^{\mathrm{a}}$ & $0.126 \pm 0.0004^{\mathrm{a}}$ & $2.980 \pm 0.060^{\mathrm{g}}$ & $5.87 \pm 0.01^{\mathrm{a}}$ \\
\hline $\mathrm{ZnCl}_{2}$ & $0.117 \pm 0.001^{\mathrm{c}}$ & $0.047 \pm 0.0004^{\mathrm{c}}$ & $0.164 \pm 0.0004^{\mathrm{c}}$ & $2.511 \pm 0.040^{\mathrm{e}}$ & $6.86 \pm 0.02^{c}$ \\
\hline $\mathrm{CaCO}_{3}$ & $0.107 \pm 0.001^{\mathrm{b}}$ & $0.041 \pm 0.0004^{\mathrm{b}}$ & $0.147 \pm 0.0003^{b}$ & $2.645 \pm 0.040^{f}$ & $6.28 \pm 0.01^{\mathrm{b}}$ \\
\hline Drought & $0.156 \pm 0.001^{\mathrm{f}}$ & $0.107 \pm 0.0006^{\mathrm{g}}$ & $0.262 \pm 0.0004^{\mathrm{g}}$ & $1.457 \pm 0.010^{\mathrm{cd}}$ & $8.50 \pm 0.02^{\mathrm{e}}$ \\
\hline $\mathrm{F}$ & 5787.79 & 18102.58 & 51951.91 & 833.42 & 467.96 \\
\hline Sig. & 0.000 & 0.000 & 0.000 & 0.000 & 0.000 \\
\hline \multirow{2}{*}{$\mathrm{T}$} & \multicolumn{5}{|c|}{ Selimiye } \\
\hline & Chl a & Chl b & Tot. Chl & $\mathrm{Chl} \mathrm{a/b}$ & Tot.Car. \\
\hline Control & $0.162 \pm 0.0005^{b}$ & $0.192 \pm 0.0002^{c}$ & $0.353 \pm 0.0001^{\mathrm{c}}$ & $0.844 \pm 0.001^{\mathrm{e}}$ & $9.11 \pm 0.005^{\mathrm{a}}$ \\
\hline $75 \mathrm{mM}$ & $0.159 \pm 0.0002^{\mathrm{a}}$ & $0.294 \pm 0.0001^{\mathrm{h}}$ & $0.452 \pm 0.0001^{\mathrm{h}}$ & $0.540 \pm 0.001^{\mathrm{a}}$ & $9.46 \pm 0.004^{\mathrm{d}}$ \\
\hline $150 \mathrm{mM}$ & $0.165 \pm 0.0002^{\mathrm{c}}$ & $0.232 \pm 0.0001^{\mathrm{e}}$ & $0.397 \pm 0.0001^{\mathrm{e}}$ & $0.710 \pm 0.001^{\mathrm{d}}$ & $9.20 \pm 0.004^{b}$ \\
\hline $225 \mathrm{mM}$ & $0.164 \pm 0.0002^{\mathrm{c}}$ & $0.253 \pm 0.0001^{\mathrm{f}}$ & $0.417 \pm 0.0001^{\mathrm{f}}$ & $0.650 \pm 0.001^{\mathrm{c}}$ & $9.26 \pm 0.136^{\mathrm{c}}$ \\
\hline $\mathrm{FeCl}_{3}$ & $0.161 \pm 0.0005^{\mathrm{b}}$ & $0.274 \pm 0.0002^{\mathrm{g}}$ & $0.435 \pm 0.0003^{\mathrm{h}}$ & $0.589 \pm 0.003^{\mathrm{b}}$ & $9.30 \pm 0.003^{\mathrm{c}}$ \\
\hline $\mathrm{NiCl} 2$ & $0.166 \pm 0.0002^{\mathrm{c}}$ & $0.175 \pm 0.0002^{\mathrm{b}}$ & $0.341 \pm 0.0002^{\mathrm{b}}$ & $0.953 \pm 0.002^{\mathrm{g}}$ & $9.42 \pm 0.029^{\mathrm{d}}$ \\
\hline $\mathrm{ZnCl}_{2}$ & $0.166 \pm 0.0005^{\mathrm{c}}$ & $0.229 \pm 0.0005^{\mathrm{e}}$ & $0.395 \pm 0.0005^{\mathrm{e}}$ & $0.724 \pm 0.001^{\mathrm{d}}$ & $9.23 \pm 0.004^{b}$ \\
\hline $\mathrm{CaCO}_{3}$ & $0.169 \pm 0.0001^{\mathrm{d}}$ & $0.189 \pm 0.0004^{c}$ & $0.358 \pm 0.0003^{c}$ & $0.893 \pm 0.002^{\mathrm{f}}$ & $9.05 \pm 0.029^{\mathrm{a}}$ \\
\hline Drought & $0.161 \pm 0.0002^{\mathrm{b}}$ & $0.155 \pm 0.0002^{\mathrm{a}}$ & $0.315 \pm 0.0002^{\mathrm{a}}$ & $1.039 \pm 0.003^{\mathrm{h}}$ & $9.54 \pm 0.004^{\mathrm{e}}$ \\
\hline $\mathrm{F}$ & 90.67 & 355.14 & 427.58 & 203.02 & 13.16 \\
\hline Sig. & 0.000 & 0.000 & 0.000 & 0.000 & 0.000 \\
\hline
\end{tabular}

T: Treatments, Chl a: Clorophyll a (mg/g), Chl b: Clorophyll b (mg/g), Tot.Chl: Total chlorophyll (mg/g), Chl a/b: Ratio of chloroğhyll a/ chlorophyll b, Tot. Car.: Total carotenoids content $(\mathrm{mg} / \mathrm{g})$, "The difference between the averages indicated by the same letter in the same column are not important $(\mathrm{P}<0.05)$ 
Table 2 Effects of salt, heavy metals, lime and drought (50\%) treatments on proline, total soluble protein, malondialdehyde (MDA)and hydrogen peroxide $\left(\mathrm{H}_{2} \mathrm{O}_{2}\right)$ in the Cumhuriyet- 75 and Selimiye-95 variety.

\begin{tabular}{|c|c|c|c|c|}
\hline \multirow{2}{*}{$\mathrm{T}$} & \multicolumn{4}{|c|}{ Cumhuriyet } \\
\hline & Prolin $(\mu \mathrm{mol} / \mathrm{g})$ & Protein $(\mathrm{mg} / \mathrm{g})$ & $\mathrm{MDA}(\mu \mathrm{mol} / \mathrm{g})$ & $\mathrm{H}_{2} \mathrm{O}_{2}(\mu \mathrm{mol} / \mathrm{g})$ \\
\hline Control & $52.96 \pm 0.17^{\mathrm{g}^{*}}$ & $25.5 \pm 0.23^{\mathrm{c}}$ & $3.19 \pm 0.08^{\mathrm{a}}$ & $15.77 \pm 0.11^{\mathrm{a}}$ \\
\hline $75 \mathrm{mM}$ & $45.21 \pm 0.02^{\mathrm{e}}$ & $44.4 \pm 0.21^{\mathrm{e}}$ & $5.07 \pm 0.07^{\mathrm{d}}$ & $24.53 \pm 0.15^{\mathrm{c}}$ \\
\hline $150 \mathrm{mM}$ & $34.97 \pm 0.02^{\mathrm{d}}$ & $49.5 \pm 0.12^{\mathrm{g}}$ & $4.94 \pm 0.13^{\mathrm{b}}$ & $59.60 \pm 0.09^{\mathrm{f}}$ \\
\hline $225 \mathrm{mM}$ & $33.27 \pm 0.02^{\mathrm{c}}$ & $48.5 \pm 0.21^{\mathrm{f}}$ & $5.26 \pm 0.08^{\mathrm{f}}$ & $32.17 \pm 0.09^{\mathrm{e}}$ \\
\hline $\mathrm{FeCl}_{3}$ & $33.36 \pm 0.02^{\mathrm{c}}$ & $35.62 \pm 0.19^{b}$ & $5.05 \pm 0.08^{\mathrm{d}}$ & $17.15 \pm 0.06^{\mathrm{b}}$ \\
\hline $\mathrm{NiCl}_{2}$ & $29.17 \pm 0.03^{\mathrm{b}}$ & $12.84 \pm 0.18^{b}$ & $5.00 .4 \pm 0.09^{c}$ & $14.83 \pm 0.09^{\mathrm{a}}$ \\
\hline $\mathrm{ZnCl}_{2}$ & $28.99 \pm 0.04^{\mathrm{b}}$ & $10.49 \pm 0.24^{\mathrm{a}}$ & $5.27 \pm 0.08^{\mathrm{f}}$ & $28.81 \pm 0.08^{\mathrm{d}}$ \\
\hline $\mathrm{CaCO}_{3}$ & $46.43 \pm 0.02^{\mathrm{f}}$ & $24.8 \pm 0.09^{c}$ & $5.18 \pm 0.09^{e}$ & $20.47 \pm 0.07^{c}$ \\
\hline Drought & $24.55 \pm 0.03^{\mathrm{a}}$ & $37.2 \pm 0.10^{\mathrm{d}}$ & $5.09 \pm 0.09^{\mathrm{d}}$ & $27.31 \pm 0.10^{\mathrm{d}}$ \\
\hline $\mathrm{F}$ & 195075.82 & 7632.92 & 551012 & 18465.97 \\
\hline Sig. & 0.003 & 0.002 & 0.001 & 0.002 \\
\hline \multirow{2}{*}{$\mathrm{T}$} & \multicolumn{4}{|c|}{ Selimiye } \\
\hline & Prolin $(\mu \mathrm{mol} / \mathrm{g})$ & Protein $(\mathrm{mg} / \mathrm{g})$ & $\mathrm{MDA}(\mu \mathrm{mol} / \mathrm{g})$ & $\mathrm{H}_{2} \mathrm{O}_{2}(\mu \mathrm{mol} / \mathrm{g})$ \\
\hline Control & $24.44 \pm 0.12^{\mathrm{a}}$ & $16.87 \pm 0.04^{\mathrm{d}}$ & $6.17 \pm 0.07^{\mathrm{g}}$ & $18.13 \pm 0.06^{\mathrm{a}}$ \\
\hline $75 \mathrm{mM}$ & $24.74 \pm 0.06^{\mathrm{a}}$ & $75.12 \pm 0.05^{1}$ & $2.75 \pm 0.05^{\mathrm{b}}$ & $43.35 \pm 0.08^{\mathrm{d}}$ \\
\hline $150 \mathrm{mM}$ & $27.66 \pm 0.09^{b}$ & $63.63 \pm 0.05^{\mathrm{h}}$ & $3.39 \pm 0.12^{\mathrm{c}}$ & $56.30 \pm 0.08^{\mathrm{g}}$ \\
\hline $225 \mathrm{mM}$ & $35.42 \pm 0.06^{\mathrm{e}}$ & $58.23 \pm 0.03^{\mathrm{g}}$ & $4.29 \pm 0.08^{\mathrm{e}}$ & $59.83 \pm 0.08^{\mathrm{h}}$ \\
\hline $\mathrm{FeCl}_{3}$ & $40.12 \pm 0.06^{\mathrm{g}}$ & $13.92 \pm 0.04^{b}$ & $4.36 \pm 0.09^{\mathrm{e}}$ & $40.32 \pm 0.09$ \\
\hline $\mathrm{NiCl}_{2}$ & $36.70 \pm 0.09^{\mathrm{f}}$ & $11.58 \pm 0.07^{\mathrm{a}}$ & $5.74 \pm 0.12^{\mathrm{f}}$ & $53.22 \pm 0.07^{\mathrm{f}}$ \\
\hline $\mathrm{ZnCl}_{2}$ & $34.08 \pm 0.06^{\mathrm{d}}$ & $15.19 \pm 0.04^{\mathrm{c}}$ & $3.68 \pm 0.09^{\mathrm{d}}$ & $38.37 \pm 0.10^{c}$ \\
\hline $\mathrm{CaCO}_{3}$ & $42.68 \pm 0.10^{\mathrm{h}}$ & $25.60 \pm 0.04^{\mathrm{e}}$ & $1.40 \pm 0.10^{\mathrm{a}}$ & $30.65 \pm 0.08^{\mathrm{b}}$ \\
\hline Drought & $33.31 \pm 0.06^{\mathrm{c}}$ & $38.85 \pm 0.03^{\mathrm{f}}$ & $3.46 \pm 0.13^{\mathrm{c}}$ & $47.26 \pm 0.06^{\mathrm{e}}$ \\
\hline $\mathrm{F}$ & 639082.59 & 350418.87 & 17623.18 & 220.93 \\
\hline Sig. & 0.003 & 0.002 & 0.001 & 0.002 \\
\hline
\end{tabular}

T: Treatments, "The difference between the averages indicated by the same letter in the same column are not important $(\mathrm{P}<0.05)$.

Table 3 Effects of salt, heavy metals, lime and drought (50\%) treatments in the APX, GuPX, CAT and SOD activities in the Cumhuriyet-75 and Selimiye-95 variety (EU/mg Protein)

\begin{tabular}{|c|c|c|c|c|}
\hline \multirow{2}{*}{$\mathrm{T}$} & \multicolumn{4}{|c|}{ Cumhuriyet } \\
\hline & APX & CAT & GuPX & SOD \\
\hline Control & $0.016 \pm 0.001^{\mathrm{d}}$ & $0.094 \pm 0.001^{\mathrm{e}}$ & $0.0310 \pm 0.0001^{\mathrm{d}}$ & $130.55 \pm 0.18^{\mathrm{h}}$ \\
\hline $75 \mathrm{mM}$ & $0.011 \pm 0.001^{\mathrm{b}}$ & $0.091 \pm 0.001^{\mathrm{e}}$ & $0.0195 \pm 0.0002^{\mathrm{a}}$ & $145.48 \pm 0.21^{\mathrm{e}}$ \\
\hline $150 \mathrm{mM}$ & $0.017 \pm 0.001^{\mathrm{d}}$ & $0.048 \pm 0.001^{\mathrm{a}}$ & $0.0180 \pm 0.0003^{\mathrm{a}}$ & $137.68 \pm 0.09^{\mathrm{d}}$ \\
\hline $225 \mathrm{mM}$ & $0.009 \pm 0.001^{\mathrm{a}}$ & $0.057 \pm 0.002^{\mathrm{b}}$ & $0.025 \pm 0.0003^{\mathrm{b}}$ & $134.37 \pm 0.13^{\mathrm{e}}$ \\
\hline $\mathrm{FeCl}_{3}$ & $0.011 * \pm 0.001^{\mathrm{b}}$ & $0.121 \pm 0.001^{\mathrm{e}}$ & $0.038 \pm 0.0006^{\mathrm{d}}$ & $129.53 \pm 0.10^{\mathrm{g}}$ \\
\hline $\mathrm{NiCl}_{2}$ & $0.014 \pm 0.001^{\mathrm{c}}$ & $0.135 \pm 0.003^{f}$ & $0.054 \pm 0.0005^{\mathrm{e}}$ & $120.53 \pm 0.17^{b}$ \\
\hline $\mathrm{ZnCl}_{2}$ & $0.021 \pm 0.001^{\mathrm{e}}$ & $0.085 \pm 0.002^{\mathrm{d}}$ & $0.027 \pm 0.0002^{c}$ & $123.46 \pm 0.15^{\mathrm{d}}$ \\
\hline $\mathrm{CaCO}_{3}$ & $0.022 \pm 0.001^{\mathrm{e}}$ & $0.090 \pm 0.001 \mathrm{~d}^{\mathrm{e}}$ & $0.030 \pm 0.0006^{\mathrm{d}}$ & $122.34 \pm 0.11^{\mathrm{c}}$ \\
\hline Drought & $0.036 \pm 0.002^{\mathrm{f}}$ & $0.073 \pm 0.001^{\mathrm{c}}$ & $0.027 \pm 0.0005^{\mathrm{c}}$ & $118.29 \pm 0.102^{\mathrm{a}}$ \\
\hline $\mathrm{F}$ & 423.15 & 1083.91 & 768.34 & 692.23 \\
\hline Sig. & 0.000 & 0.000 & 0.000 & 0.000 \\
\hline \multirow{2}{*}{$\mathrm{T}$} & \multicolumn{4}{|c|}{ Selimiye } \\
\hline & APX & CAT & GuPX & SOD \\
\hline Control & $0.073 \pm 0.001^{\mathrm{c}}$ & $0.102 \pm 0.001^{1}$ & $0.012 \pm 0.0001^{\mathrm{d}}$ & $139.69 \pm 0.01^{\mathrm{d}}$ \\
\hline $75 \mathrm{mM}$ & $0.153 \pm 0.002^{\mathrm{f}}$ & $0.093 \pm 0.001^{\mathrm{d}}$ & $0.015 \pm 0.0003^{\mathrm{f}}$ & $172.82 \pm 0.26^{\mathrm{h}}$ \\
\hline $150 \mathrm{mM}$ & $0.141 \pm 0.003^{\mathrm{e}}$ & $0.084 \pm 0.001^{\mathrm{f}}$ & $0.013 \pm 0.0002^{\mathrm{e}}$ & $158.57 \pm 0.22^{\mathrm{g}}$ \\
\hline $225 \mathrm{mM}$ & $0.131 \pm 0.002^{\mathrm{e}}$ & $0.078 \pm 0.001^{\mathrm{h}}$ & $0.011 \pm 0.0002^{\mathrm{de}}$ & $152.56 \pm 0.21^{\mathrm{f}}$ \\
\hline $\mathrm{FeCl}_{3}$ & $0.134 \pm 0.015^{\mathrm{b}}$ & $0.071 \pm 0.001^{\mathrm{e}}$ & $0.014 \pm 0.0005^{\mathrm{c}}$ & $129.66 \pm 0.44^{\mathrm{c}}$ \\
\hline $\mathrm{NiCl}_{2}$ & $0.026 \pm 0.001^{\mathrm{a}}$ & $0.059 \pm 0.001^{\mathrm{g}}$ & $0.007 \pm 0.0001^{\mathrm{a}}$ & $126.13 \pm 0.05^{\mathrm{a}}$ \\
\hline $\mathrm{ZnCl}_{2}$ & $0.070 \pm 0.001^{\mathrm{c}}$ & $0.042 \pm 0.001^{\mathrm{c}}$ & $0.008 \pm 0.0001^{\mathrm{b}}$ & $127.32 \pm 0.01^{\mathrm{b}}$ \\
\hline $\mathrm{CaCO}_{3}$ & $0.078 \pm 0.001^{\mathrm{cd}}$ & $0.043 \pm 0.001^{\mathrm{b}}$ & $0.011 \pm 0.0001^{\mathrm{c}}$ & $148.77 \pm 0.27^{\mathrm{e}}$ \\
\hline Drought & $0.096 \pm 0.002^{\mathrm{d}}$ & $0.038 \pm 0.001^{\mathrm{a}}$ & $0.014 \pm 0.0003^{\mathrm{f}}$ & $147.87 \pm 0.27^{\mathrm{e}}$ \\
\hline $\mathrm{F}$ & 93.85 & 6663.57 & 402.79 & 4508.96 \\
\hline Sig. & 0.000 & 0.000 & 0.000 & 0.000 \\
\hline
\end{tabular}

T: Treatments, ${ }^{*}$ The difference between the averages indicated by the same letter in the same column are not important $(\mathrm{P}<0.05)$. 
The amount of malondialdehyde (MDA) was observed higher in all types of stress treatments in Cumhuriyet-75 variety compared to control group, but it lowered in leaf samples of Selimiye-95 variety (Table 3). In Cumhuriet75 in $\mathrm{ZnCl}_{2}(5.27 \mu \mathrm{mol}), 225 \mathrm{mM} \mathrm{NaCl}(5.26 \mu \mathrm{mo}$, $\mathrm{CaCO}_{3}(5.18 \mu \mathrm{mol})$ treatments MDA level was the highest level respectively. Chlorophyll b, total chlorophyll and carotenoid contents increased in salt concentrations, $\mathrm{FeCl}_{3}, \mathrm{ZnCl}_{2}$ and $\mathrm{CaCO}_{3}$ treatments $(\mathrm{P}<0.05$; Table 1). There was a decrease in $\mathrm{H}_{2} \mathrm{O}_{2}$ concentration $6 \%$ only in $\mathrm{NiCl}_{2}$ treatment $(14.83$ $\mu \mathrm{mol})$ in the Cumhuriyet-75 variety compared to control group $(15.77 \mu \mathrm{mol})$ (Table 2$)$. But in Selimiye-95 variety $\mathrm{H}_{2} \mathrm{O}_{2}$ concentration showed significant increase in all treatment groups compared to control, especially in 225 $\mathrm{mM}(59.83 \mu \mathrm{mol}), 150 \mathrm{mM}(56.30 \mu \mathrm{mol}) \mathrm{NaCl}$ and $\mathrm{NiCl}_{2}(53.22 \mu \mathrm{mol})$ treatments (Table 2$)$.

There were significant differences between enzyme activities of wheat varieties $(\mathrm{P}<0.05)$. The level of APX (ascorbate peroxidase), CAT (catalase), GuPX (guaiacol peroxidae) and SOD (superoxide dismutase) activities were higher in Selimiye-95 than Cumhuriyet-75. However in Cumhuriyet APX activity was found higher in drought (2.31 time), $\mathrm{CaCO}_{3}(38.93 \%), \mathrm{ZnCl}_{2}(32.1 \%)$ and $150 \mathrm{mM}(5.17 \%)$ with respect to control. CAT and GuPX activity were higher in $\mathrm{NiCl}_{2}(0.195 \mathrm{EU}$ and 0.054 EU) and $\mathrm{FeCl}_{3}(0.121 \mathrm{EU}$ and $0.038 \mathrm{EU})$ but lower in all other treatments. The lowest activity was determined in $150 \mathrm{mM} \mathrm{NaCl}$ for both enzymes as $0.48 \mathrm{EU}$ and $0.18 \mathrm{EU}$ in order. SOD activity was higher value of salt treatments, but it was reduced with cocentrations (Table 3). In Selimiye APX activity increased with salts (0.153 EU, $0.141 \mathrm{EU}, 0.131 \mathrm{EU})$ and $\mathrm{FeCl}_{3}(0.134 \mathrm{EU})$ application but CAT activity decreased in all treatments, especially in heavy metals and $225 \mathrm{mM} \mathrm{NaCl}$ applications. GuPX activity reduced heavy metals $(0.007 \mathrm{EU}, 0.008,0.011$ EU) and in $225 \mathrm{MM} \mathrm{NaCl}(0.011 \mathrm{EU})$ while SOD were determined lower in only heavy metals (129.66 EU, 126.12 EU, 127.32 EU) (Table 3).

\section{Discussion}

Photosynthetic pigments have a central role in capturing light, driving electron transport and generation of chemical energy and reducing power in the form of ATP and NADPH, respectively. Their content in photosynthetic active tissue varies depends on genotype, maturity of leaf and whole plant and also environmental conditions such as climatic factors, mineral status of soil, drought and salty (Molas, 2002; Raines, 2011). The amount of chlorophyll a, b, total chlorophyll and carotenoid were higher in Selimiye generally but there was no significant difference between species in terms of chlorophyll $\mathrm{a} / \mathrm{b}$ ratio (Table 1). In Cumhuriyet photosynthetic pigments were most influenced by $\mathrm{NiCl}_{2}$, $\mathrm{ZnCl}_{2}, \mathrm{CaCO}_{3}$ treatments negatively. The amount of chlorophyll $\mathrm{b}$ and total chlorophyll were the highest at $\mathrm{FeCl} 3$ in both varities but they were lowest in $\mathrm{NiCl}_{2}$ for Cumhuryet-75 and in drought for Selimiye-95 (Table 1). Photosynthetic pigment results showed that Cumhuriyet75 is more sensitive to $\mathrm{NiCl} 2, \mathrm{ZnCl}_{2}, \mathrm{CaCO}_{3}$ but it is tolerant to $\mathrm{FeCl}_{3}$, drought and $225 \mathrm{mM} \mathrm{NaCl}$ treatments. On the other hand Selimiye-95 sowed sensitivity to drought and $\mathrm{NiCl}_{2}$ but was found resistant to salts and $\mathrm{FeCl}_{3}$ treatments (Table 1). Photosynthetic pigment results are similar to those found in this field. For example Öncel and Keleş (2002), Parida et al. (2002), Santos (2002) reported that chlorophyll content was higher in leaves of tolerant cultivars while Kholová et al. (2010), Terzi and Y1ldiz (2013) stated that pigment levels were lower in salts condition in susceptible. However they noted that their content may be lower at the beginning of growth phase but they can higher by the age of maturity in plant. Kumar et al (2012), Dubey and Pandey (2011) in heavy metal the amount of chlorophyll pigment reduced in susceptible crops. It has been expressed that iron (Fe) toxicity (Schmidt and Fühner 1998; Molas 2002), zinc (Zn) toxicity in agricultural soils (Nagaiyot et al., 2010) repressed chlorophyll synthesis, stimulated leaf chlorosis due to iron deficiency, and inhibit the absorption of phosphorus and iron. On the other hand Gruber and Kosegarten (2002) found that chlorine areas in leaves increase due to iron lacking and inhibition of chlorophyll synthesis in grapes in calcareous soil. In sensitive varieties decreasing in chlorophyll under salt, drought, heavy metal and limy stresses is mainly the result of damage to chloroplast membrane, increasing of chlorophyll and protein degradation, decreasing biosynthesis and inhibition enzymes which responsible of biosynthesis of chlorophyll pigment by stimulated oxidative reactions (Sairam et al. 205; Foyer and Shigeoka 2011). Total carotenoids areless affected by drought than chlorophyll (Efeoglu and Terzioglu, 2009). Our carotenoid findings are consistent with this information especially in Selimiye-95.

One of the most abundant compounds in plant tissues is soluble nitrogen compounds. Researchers stated that prolines and total soluble proteins are necessary at all stages of growth (Parida et al., 2002; Sharma and Dietz, 2006). The content of proline was very lower compared to the control group in the stress treatment groups in the Cumhuriyet-75 but it was higher in Selimiye-95 in all applications (Table 2). In Cumhuriyet the amount of proline was the lowest value especially in drought, heavy metals $\left(\mathrm{ZnCl}_{2}, \mathrm{NiCl}_{2}\right.$, and $\left.\mathrm{FeCl}_{3}\right)$ treatments while it was maximum level at $\mathrm{CaCO}_{3}$ and $\mathrm{FeCl}_{3}$ (Table 2). Within the scope of total soluble protein quantity changes heavy metals and drought have decreased the amount of it in both wheat varieties and also it increased with salt concentrations (Table 2). The results of proline and protein are in agreement with other investigations. Demiral and Türkan (2005), Turkyılmaz et al. (2014), determined that proline level increased in tolerant genotypes order under salty conditions; Keyvan (2010), Razi et al. (2016), found that by drought cause an increase proline content in resistant species. Chen et al. (2001), Sharma and Dietz (2006) observed that proline content reduced by excess elements and heavy metals, and also Gregersen et al. (2008), Çakmak et al. (2001) noted that exposed to limy stress decreased level of it in susceptible plants. It has been proven that protein content was higher in resistant compared to susceptible species and varieties in salt stress by Ashraf and Harris (2004) and Crawford (1995), and drought conditions by Başer et al. (2005), Parida et al. (2007). Chen et al. (2001), Singh and Tewari (2003), found that excess levels of heavy metals $(\mathrm{Zn}, \mathrm{Cu}$, 
$\mathrm{Cd}, \mathrm{Co}, \mathrm{Pb}, \mathrm{Ni}$ and $\mathrm{Ag}$ ) inhibit the binding of metals to sulfhydryl groups in amino acids and proteins. As a result of this may repress its synthesis and impaire the functions (Davies, 1987; Sharma and Dietz, 2006). It has been reported that tolerance genotypes accumulate more osmolytes such as proline and soluble proteins during stress conditions and play an important role in prevention of the cellular structures and components (Szabados and Savoure 2009). And also proteins can caatbolise to proline (Kavir Kishor et al., 2005) while proline can metabolize to glucose and cause synthesis of chlorophyll by glutamate pathway (Sharma et al., 2011). It was found out that $\mathrm{n}$ cumhuriyet SOD activity is higher as protein content increases but CAT and GuPX activity are lower with higher MDA and $\mathrm{H}_{2} \mathrm{O}_{2}$ levels. However CAT andd GuPX activities are the highest value at lowest $\mathrm{H}_{2} \mathrm{O}_{2}$ level. APX is maximum activity due to higher protein in drought (Table 2, Table 3). In Selimiye CAT activity is lower due to higher $\mathrm{H}_{2} \mathrm{O}_{2}$ concentration but APX and SOD activity are higher by higher proline, soluble protein as well lower MDA. SOD activity is lower at heavy metals concentrations (Table 2, Table 3 ).

Results of MDA, $\mathrm{H}_{2} \mathrm{O}_{2}$ and enzyme activities are similar to other works of researchers which determined that ROS, MDA level were higher by abiotic stress conditions such as salinity, drought, heavy metals. For example Sairam et al. (2005) investigated that effect of long-term sodium chloride salinity in tolerant and susceptible wheat genotypes. They found that salt treatment decreased membrane stability index (MSI), activities of SOD, APX and GR but increased the contents of $\mathrm{H}_{2} \mathrm{O}_{2}$. Turky1lmaz et al. (2014) determined that the activities of APX, CAT, POX and SOD increased in tolerant barley seedling significantly under $\mathrm{NaCl}$ stress while Kholová et al. (2010) measured that $\mathrm{NaCl}$ decreased antioxidant enzymes in maize genotypes. Sofo et al. (2015), Razi et al. (2016), have reported that enzyme activities are decreased in susceptible varietiesin drought conditions; Singh and Tewari (2003) and Pandey and Sing (2011) have reported that concentrations of heavy metals ( $\mathrm{Fe}, \mathrm{Cd}, \mathrm{Cu}, \mathrm{Zn}, \mathrm{Ni}, \mathrm{Pb}$ ) reduce $\mathrm{SOD}, \mathrm{APX}, \mathrm{CAT}$ activities in safflower, rice and spinach respectively.

As a result, it was shown in this study that the differences in growth, photosynthetic pigments as chlorophyll a, chlorophyll b, total chlorophyll and carotenoid contents, proline and soluble protein content, lipid peroxidation, hydrogen peroxide, and antioxidant activities such as APX, CAT, GuPX and SOD Activities in the two wheat cultivars could be ascribed for determination of salt, heavy meals, drought and calcareous stress effects on resistance mechanisms of wheat genotypes. Depends on chemical compound results Selimiye-95 variety is more resistant to $\mathrm{NaCl}, \mathrm{FeCl} 3$ and limedrought but it showed moderate tolerance to $\mathrm{CaCO}_{3}$. Cumhuriyet-75 cultivar was found as sensivite types comparison to Selimiye but it is tolerant to drought, $\mathrm{FeCl}_{3}$ and $225 \mathrm{mM} \mathrm{NaCl}$.

\section{Acknowledgement}

This study has been carried out by virtue of the assistance provided through the of KUBAP-01 / 2013-17 project.

\section{References}

Arnon D. 1949. Coppere enzymes in isolated chloroplasts: Polyphenoloxydase in Beta vulgaris. Plant Physiol. 24:1-15.

Ashraf M, Harris PJC. 2004. Potential biochemical indicators of salinity tolerance in plants. Plant Sci. 166: 3-16.

Başer İ, Korkut KZ, Bilgin O. 2005. Ekmeklik buğdayda (Triticum aestivum L.) kurağa dayanıklılıkla ilgili özellikler arasındaki ilişkiler. Tekirdağ Ziraat Fakültesi Dergisi. 2 (3).

Bates LS, Waldren RP, Teare ID. 1973. Rapid determination of proline for water-stress studies. Plant and Soil. 39: 205-207.

Bergmeyer HU. 1974. Methods of Enzymatic Analysis. New York, Academic Press.

Blake NK, Lanning SP, Martin JM, Sherman JD, Talbert LE (2007). Relationship of flag leaf characteristics to economically important traits in two spring wheat crosses. Crop Sci. 47:491-494.

Bradford M. 1976. A Rapid and Sensitive Method for the Quantitation of Microgram Quantities of Protein Utilizing the Principle of Protein-Dye Binding. Anal Biochem. 72:248-254.

Chance B, Maehly SK. 1995. Assay of catalase and peroxidase”, Methods Enzymol. 2:764-775.

Chen CT, Chen LM, Lin CC, Kao CH. 2001. Regulation of proline accumulation in detached rice leaves exposed to excess copper. Plant Sci. 160: 283-290.

Crawford NM. 1995. Nitrate: nutrient and signal for plant growth. The Plant Cell. 7: 859-868.

Çakmak I. 1994. Activity of ascorbate-dependent $\mathrm{H}_{2} \mathrm{O}_{2}$ scavenging enzymes and leaf chlorosis are enhancedin magnesium and potassium deficient leaves, but not in phosphorus deficient leaves. Journal of Experimental Botany. 45: 1259-1266.

Çakmak O, Öztürk L, Karanlık S, Özkan H, Kaya Z, Çakmak İ. 2001. Tolerance of 65 durum wheat genotypes to zinc deficiency in a calcareous soil. J. Plant Nutr. 24: 1831-1847.

Çimen B, Yeşiloğlu T, Yılmaz B, İncesu M. 2013. Farklı Tuz Konsantrasyonlarının Bazı Turunçgil Anaçlarının Fotosentetik Performansları Üzerine Etkileri”, Tarım Bilimleri Araştırma Dergisi. 6 (2):13-18.

Davies KJA. 1987. Protein damage and degradation by oxygen radicals I. General aspects. J Biochem Chem. 262: 98959901.

Demiral T, Türkan I. 2005. Comparative lipid peroxidation, antioxidant defense systems and proline content in roots of two rice cultivars differing in salt tolerance. Environmental and Exp Bot. 53: 247-257.

Dubey D, Pandey A. 2011. Effect of Nickel (Ni) On Chlorophyll, Lipid Peroxidation and Antioxidant Enzymes Activities In Black Gram (Vigna Mungo) Leaves. I.J.S.N. (2) 2011:395-40.

Efeoglu B, Terzioglu S. 2009. Photosynthetic responses of two wheat varieties to high temperature. EurAsia J. BioSci. 3: 97-106.

Foyer CH, Shigeoka S. 2011. Understanding Oxidative Stress and Antioxidant Functions to Enhance Photosynthesis. Plant Physiology. 155 (1): 93-100.

Gregersen PL, Holm PB, Krupinska K. 2008. Leaf senescence and nutrient remobilisation in barley and wheat. Plant Biology. 10: 37-49.

Gruber B, Kosegarten H. 2002. Depressed growth of nonchlorotic vine grown in calcareous soil is an iron deficiency symptom prior to leaf chlorosis. J. Plant Nutr. and Soil Sci. 165: 11-117.

Gupta NK, Gupta S, Kumar A. 2001. Effect of water stress on physiological attributes and their relationship with growth and yield of wheat cultivars at different stages. Crop Science, 41: 1390-1395.

Halliwell B, Gutteridge JMC. 2012. Free Radical in Biology and Medicine, Oxford University Press, UK, 1999, 3rd edn. 
Hernandez JA, Almansa MS. 2002. Short-term effects of salt stress on antioxidant systems and leaf water relations of pea plants. Physiol. Plant. 115(2): 251-257.

Kavir Kishor PB, Sangam S, Amrutha RN, Sri Laxmi P, Naidu KR, Rao KRSS, Rao S, Reddy KJ, Sreenivasulu N. 2005. Regulation of proline biosynthesis, degradation, uptake and transport in higher plants: Its implications in plant growth and abiotic stress tolerance. Cur Sci. 88: 424-438.

Keyvan S. 2010. The effects of drought stress on yield, relative water content, proline, soluble carbohydrates and chlorophyll of bread wheat cultivars. Journal of Animal and Plant Sciences. 8(3): 1051-1060.

Kholová J, Sairam RK, Meena RC. 2010. Osmolytes and metal ions accumulation, oxidative stress and antioxidant enzymes activity as determinants of salinity stress tolerance in maize genotypes. Acta Physiologiae Plantarum. 32: 477-486.

Kumar V, Awasthi G, Chauhan PK. 2012. Cu and Zn tolerance and responses of the Biochemical and Physiochemical system of Wheat. Journal of Stress Physiology \& Biochemistry. 8 (3): 203-213.

Lutts S, Kinet, JM, Bouharmont J. 1996. $\mathrm{NaCl}$ induced senescence in leaves of rice (Oryza sativa L.) cultivars differing in salinity resistance. Annals of Botany. 78:389398.

Makino A. 2001. Photosynthesis, Grain Yield, and Nitrogen Utilization in Rice and Wheat. Plant Physiology. 155 (1):125-29.

Molas J. 2002. Changes of chloroplast ultrastructure and total chlorophyll concentration in cabbage leaves caused by excess of organic Ni (II) complexes. Environ. Exp. Bot. 47:115-126.

Nagaiyot PC, Lee KD, Sreekanth TVM. 2010. Heavy metals, occurrence and toxicity for plants: a review. J. Environ Chem Lett. 8 (3): 199-216.

Nagoor S. 1999. Physiological and biochemical responses of cereal seedlings to graded levels of heavy metals. II. Effects on protein metabolism in maize seedlings. Adv. Plant Sci. 12: 425-433.

Nakano Y, Asada K. 1981. Hydrogen peroxide is scavenged by ascorbate specific peroxidase in spinach chloroplasts. Physiologia Plantarum. 115: 393-400.

Neto ADA, Prisco JT, Enéas-Filho J, Abreu CEB, Gomes-Filho E. 2006. Effect of salt stress on antioxidative enzymes and lipid peroxidation in leaves and roots of salt-tolerant and salt-sensitive maize genotypes. Environmental and Experimental Botany. 56: 87-94.

Öncel I, Keleş Y. 2002. Tuz Stresi Altındaki Buğday Genotiplerinde Büyüme, Pigment İceriği ve Çözünür Madde Kompozisyonunda Değişmeler. C.Ü. Fen-Edebiyat Fakültesi Fen Bilimleri Dergisi. 23(2): 9-16.

Öz A, Cegil Bekir. 2016. A study on adaptation of some maize cultivar in Middle Kizılırmak Basin. Journal of Applied Biological Sciences. 10 (1): 01-07.

Özturk A, Aydin F. 2004. Effect of water stress at various growth stages on some quality characteristics of winter wheat. J. Agronomy \& Crop Science. 190: 9399.

Pandey SN, Sing K. 2011. Effect of nickel-stresses on uptake, pigments and antioxidative responses of water lettuce, Pistia stratiotes L. J. Environ. Biol. 32: 391-394.

Parida AK, Dagaonkar VS, Phalak MS. 2007.Alterations in photosynthetic pigments, protein and osmotic components in cotton genotypes subjected to short-term drought stress followed by recovery. Plant Biotechnol. Rep. 1: 37-48.

Parida AK, Das AB, Das P. 2002. NaCl stress causes changes in photosynthetic pigments, proteins and other metabolic components in the leaves of a true mangrove, Bruguiera parviflora, in hydroponic cultures. J. Plant Biol. 45: 28-36.
Pattanagul W, Thitisaksakul M. 2008. Effect of Salinity stress on growth and carbohydrate metabolism in tree rice (Oryza sativa) cultivars in differing salinity tolerance. Indian Journal of Experimental Biology. 46: 735-742.

Raines CA. 2011. Increasing Photosynthetic Carbon Assimilation in C3 Plants to Improve Crop Yield: Current and Future Strategies. Plant Physiology. 155 (1): 36-42.

Razi H, Zahedi MB, Saed-Moucheshi A. 2016. Evaluation of Antioxidant Enzymes, Lipid Peroxidation and Proline Content as Selection Criteria for Grain Yield under Water Deficit Stress in Barley. Journal of Applied Biological Sciences. 10 (1): 71-78.

Sairam RK, Srivastava, GC, Agarwal S, Meena RC. 2005. Differences in antioxidant activity in response to salinity stress in tolerant and susceptible wheat genotypes. Biologia Plantarum. 49: 85-91.

Santos CV. 2004. Regulation of chlorophyll biosynthesis and degradation by salt stress in sunflower leaves. Scientia Horticulturae. 103: 93-99.

Schmidt W, Fühner C. 1998. Sensitivity to and requirement for iron in Plantago species. The New Phytologist. 138: 639651.

Sharma S, Villamor JG, Versules PE. 2011. Essential role of tissue-specific proline synthesis and catabolism in growth and redox balance at low water potential", Plant Physiology. 157 (1): 292-304.

Sharma SS, Dietz KJ. 2006. The significance of amino acids and amino acid-derived molecules in plant responses and adaptation to heavy metal stress. Journal of Experimental Botany. 57: 711-726.

Singh PK, Tewari RK. 2003. Cadmium toxicity induced changes in plant water relations and oxidative metabolism of Brassica juncea L. Plants", J. Environ. Biology. 24: 107-112.

Sofo A, Scopa A, Nuzzacc1 M, Vitti A. 2015. Ascorbate Peroxidase and Catalase Activities and Their Genetic Regulation in Plants Subjected to Drought and Salinity Stresses. Int. J. Mol. Sci. 16: 13561-13578.

Spiteller G. 2003. The relationship between cell wall, lipid peroxidation, proliferation, senescence and cell death. Physiol. Plant. 119: 5-18.

Szabados L, Savoure A. 2009. Proline: a multifunctional amino acid. Trends Plant Sci. 2: 89-97.

Terzi H, Y1ldiz M. 2013. Effect of $\mathrm{NaCl}$ Stress on Chlorophyll Biosynthesis, Proline, Lipid Peroxidation and Antioxidative Enzymes in Leaves of Salt-Tolerant and Salt-Sensitive Barley Cultivars. Tarım Bilimleri Dergisi-Journal of Agricultural Sciences. 19 :79-88.

Turkyılmaz Unal B, Aktaş LY, Güven A. 2014. Effects of salinity on antioxidant enzymes and proline in leaves of barley seedlings in different growth stages. Bulg. J. Agric. Sci. 20: 883-887.

Velikova V, Yordanov I, Edreva A. 2000. Oxidative stress and some antioxidant systems in acid rain-treated bean plants: protective roles of exogenous polyamines. Plant Sci. 151: 59-66.

Waters BM, Uauy C, Dubcovsky J, Grusak MA. 2009. Wheat (Triticum aestivum) proteins regulate the translocation of iron, zinc, and nitrogen compounds from vegetative tissues to grain. Journal of Experimental Botany. 60(15): 42634274.

Witham FH, Blaydes DF, Devli RM. 1971. Experiments in plant physiology. 55-56. Van Nostrand Reinhold Company, New York.

Zheng Y, Xu X, Li Z, Yang X, Zhang C, Li F, Jiang G. 2009. Differential responses of grain yield and quality to salinity between contrasting winter wheat cultivars. Seed Sci. Biotech. 3: 40-43 